\title{
Evaluasi Penggunaan Obat Antihipertensi pada Pasien Gagal Jantung Rawat Jalan di Rumah Sakit Umum Daerah Provinsi Nusa Tenggara Barat
}

\author{
Baiq Leny Nopitasaria ${ }^{a} 1^{*}$, Baiq Nurbaetya,2, Hafni Zuhroh ${ }^{a, 3}$ \\ a Program Studi Farmasi, Fakultas Ilmu Kesehatan, Universitas Muhammadiyah Mataram, Mataram, Indonesia \\ ${ }^{1}$ baiqleny.nopitasari@gmail.com; ${ }^{*}$ bq.tyee@gmail.com; ${ }^{3 h}$ afnizuhrah99@gmail.com \\ korespondensi penulis
}

\begin{tabular}{|c|c|}
\hline INFO ARTIKEL & ABSTRAK \\
\hline $\begin{array}{l}\text { Diterima : } \\
\text { 25-06-2020 } \\
\text { Disetujui : } \\
\text { 04-07-2020 }\end{array}$ & $\begin{array}{l}\text { Gagal jantung adalah ketidakmampuan jantung memompa darah guna } \\
\text { memenuhi kebutuhan oksigen serta memberikan nutrisi jaringan } \\
\text { tubuh. Gagal jantung biasanya disebabkan oleh kelainan sekunder dari } \\
\text { abnormalitas struktur jantung atau fungsi yang merusak kemampuan } \\
\text { ventrikel kiri untuk mengisi atau mengeluarkan darah. Keberhasilan }\end{array}$ \\
\hline $\begin{array}{l}\text { Kata kunci: } \\
\text { Evaluasi Penggunaan Obat; } \\
\text { Antihipertensi; } \\
\text { Gagal Jantung. }\end{array}$ & $\begin{array}{l}\text { penanganan secara medis tapi juga ditentukan oleh ketepatan dalam } \\
\text { penggunaan obat. Penelitian ini bertujuan untuk mengevaluasi } \\
\text { ketepatan pengobatan antihipertensi pada pasien gagal jantung di poli } \\
\text { jantung RSUD Provinsi NTB pada bulan April-Mei tahun } 2019 \text {. } \\
\text { Penelitian ini menggunakan metode deskriptif dengan pendekatan } \\
\text { cross sectional. Penelitian dilakukan terhadap } 49 \text { catatan rekam medis } \\
\text { pasien yang mendapatkan terapi antihipertensi dengan gagal jantung. } \\
\text { Hasilnya menunjukan bahwa ketepatan penggunan obat } \\
\text { antihipertensi pada pasien gagal jantung di RSUD Provinsi NTB } \\
\text { tahun } 2019 \text { yaitu tepat indikasi sebesar IO0\%, tepat pasien sebesar } \\
\text { I00\%, tepat obat sebesar I00\%, tepat dosis sebesar } 73,54 \% \text { dan } \\
\text { tepat frekuensi sebesar I00\%. }\end{array}$ \\
\hline
\end{tabular}

\section{Keywords:}

Evaluation of drug use; antihypertensive;

heart failure.

\section{ABSTRACT}

Heart failure is the inability of the heart to pump blood to meet oxygen needs and provide nutrition for body tissues. Heart failure is usually caused by a secondary disorder of abnormal heart structure or function that damages the ability of the left ventricle to fill or bleed. Medical treatment success but also determined by the accuracy in the use of drugs. This study aims to evaluate the accuracy of antihypertensive treatment in heart failure patients in the heart poly of the NTB Provincial Hospital in April-May 2019. This study used a descriptive method with a cross sectional approach. The study was conducted on 49 medical record records of patients receiving antihypertensive therapy with heart failure. The results showed that the accuracy of the use of antihypertensive drugs in heart failure patients in the NTB Provincial Hospital in 2019 was seen based on the exact indication of $100 \%$, the right patient at $100 \%$, the exact drug at $100 \%$, the right dose of $73,54 \%$ and the exact frequency of $100 \%$.

This is an open access article under the $\mathrm{CC}-\mathrm{BY}-\mathrm{SA}$ license.

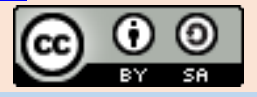

\section{Pendahuluan}

Gagal jantung adalah ketidakmampuan jantung memompa darah guna memenuhi kebutuhan oksigen serta memberikan nutrisi jaringan tubuh. Gagal jantung biasanya disebabkan oleh kelainan sekunder dari abnormalitas struktur jantung dan atau fungsi 
(yang diturunkan atau didapat) yang merusak kemampuan ventrikel kiri untuk mengisi atau mengeluarkan darah.

Menurut data dari World Health Organization (WHO) tahun 2016, tercatat sebanyak 17,5 juta orang di dunia meninggal akibat gangguan kardiovaskular. Berdasarkan data Riset Kesehatan Dasar (Riskesdas) tahun 2018, prevalensi penyakit jantung di Indonesia sebesar 1,5\%. \%). Prevalensi gagal jantung di Nusa Tenggara Barat berdasarkan terdiagnosis dokter sebesar 0,9 persen.

Penyebab utama gagal jantung adalah penyakit kardiovaskuler seperti hipertensi, kardiomiopati dan penyakit jantung koroner, yang dapat menyebabkan disfungsi ventrikel kiri berupa penurunan kemampuan kontraksi, relaksasi atau keduanya yang berdampak pada penurunan curah jantung. Gagal jantung juga dapat disebabkan oleh penyakit metabolik seperti hipertiroidisme dan anemia, dimana pada keadaan tersebut tubuh membutuhkan curah jantung yang lebih tinggi dari normal.Tatalaksana hipertensi dan penyakit arteri koroner sangat diperlukan dalam pencegahan dan penanganan gagal jantung

Evaluasi penggunaan obat (EPO) merupakan proses jaminan mutu resmi dan terstruktur yang dilaksanakan terus menerus, yang ditujukan untuk menjamin obat yang tepat, aman dan efektif.

\section{Metode}

Penelitian ini menggunakan desain observasional dengan metode deskriptif. Pengumpulan data dilakukan dengan pendekatan cross sectional dari catatan medik pasien gagal jantung dengan hipertensi di Instalasi Rawat Jalan RSUD Provinsi Nusa Tenggara Barat periode April 2019. Penelitian ini dilaksanakan di Poliklinik Penyakit Jantung Instalasi Rawat Jalan RSUD Provinsi Nusa Tenggara Barat periode April 2019.

Populasi target dalam penelitian ini adalah seluruh pasien dengan diagnosis utama gagal jantung yang sedang menjalani rawat jalan di poliklinik penyakit jantung selama periode penelitian. Sampel adalah sebagian yang diambil dari keseluruhan objek yang diteliti dan dianggap mewakili seluruh populasi. Sampel penelitian adalah pasien dengan diagnosa gagal jantung yang mendapatkan terapi obat antihipertensi yang menjalani rawat jalan di Poliklinik Penyakit Jantung Rumah Sakit Umum Daerah Provinsi Nusa Tenggara Barat yang memenuhi kriteria inklusi dan eksklusi. Kriteria inklusi pada penelitian ini adalah semua pasien gagal jantung yang menggunakan terapi antihipertensi.

Dalam penelitian ini penulis menggunakan teknik pengambilan sampel dengan menggunakan Consecutive sampling, yaitu pemilihan sampel dengan menetapkan subjek yang memenuhi kriteria penelitian. Dimasukkan dalam penelitian sampai kurun waktu tertentu, sehingga jumlah sampel dapat terpenuhi.

Data yang dikumpulkan dari rekam medik, dimana data yang diperoleh adalah data pasien gagal ginjal kronik yang memenuhi kriteria pasien dalam penelitian yang meliputi; umur, jenis kelamin, penyakit penyerta dan yang menggunakan terapi antihipertensi kemudian dianalisa secara deskriptif. Penelitian ini dilakukan setelah mendapat izin penelitian dari direktur RS dengan nomor izin penelitian 070/2039/RSUDP NTB

Kriteria yang digunakan dalam menilai ketepatan obat meliputi; Tepat pasien adalah pemilihan obat yang sesuai dengan indikasi gejala pasien dan pemilihan obat yang tidak kontra indikasi terhadap pasien gagal jantung. Tepat indikasi adalah keputusan pemilihan obat yang diresepkan didasari indikasi penyakit serta pemilihan terapi obat yang efektif dan aman. Tepat obat adalah pemilihan obat sesuai dengan drug of choice/ obat pilihan utama, yang aman digunakan untuk pasien gagal jantung. Tepat dosis adalah pemilihan dosis yang tepat untuk pasien yang disertai dengan frekuensi pemberian obatnya yang disesuaikan dengan Drug Dosing Heart Failure. Tepat frekuensi atau interval pemberian obat adalah ketepatan pemberian obat sesuai dengan sifat obat dan profil farmakokinetiknya.

Evaluasi ketepatan dilakukan dengan membandingkan aspek-aspek penggunaan obat antihipertensi di lapangan dengan kriteria penggunaan yang telah ditetapkan oleh Formularium RSUDP, Formularium Nasional, Perhimpunan Dokter Kardiovaskular Indonesia, Guideline Heart Failure 2017, dan Guideline JNC VIII dan disajikan dalam bentuk persentase.

\section{Hasil dan pembahasan}

Penelitian ini dilakukan oleh peneliti di RSUD Provinsi Nusa Tenggara Barat yang merupakan upaya untuk mengevaluasi penggunaan obat antihipertensi pada pasien gagal jantung. Penelitian dilakukan dalam kurun 
waktu I bulan dimulai dari pertengahan April hingga awal bulan Mei 2019. Pengambilan data menggunakan data rekam medik pasien yang menjalani rawat jalan di rumah sakit tersebut. Terdapat 49 pasien yang sesuai dengan kriteria inklusi di RSUD Provinsi Nusa Tenggara Barat pada bulan April hingga Mei 2019. Semua pasien yang masuk dalam kriteria inklusi merupakan pasien gagal jantung yang telah mendapatkan terapi antihipertensi.

Tabel I Karakteristik pasien gagal ginjal kronik

\begin{tabular}{|c|c|c|c|c|c|}
\hline \multirow{2}{*}{$\begin{array}{l}\mathrm{N} \\
\mathrm{o}\end{array}$} & \multirow{2}{*}{$\begin{array}{c}\text { Usia } \\
\text { (tahu } \\
\mathrm{n})\end{array}$} & \multicolumn{2}{|c|}{ Laki-laki } & \multicolumn{2}{|c|}{ Perempuan } \\
\hline & & $\begin{array}{c}\text { Juml } \\
\text { ah }\end{array}$ & $\begin{array}{l}\text { Persent } \\
\text { ase }(\%)\end{array}$ & $\begin{array}{c}\text { Juml } \\
\text { ah }\end{array}$ & $\begin{array}{l}\text { Persent } \\
\text { ase (\%) }\end{array}$ \\
\hline $\bar{I}$ & $\begin{array}{c}26- \\
45\end{array}$ & 2 & $4,08 \%$ & 8 & $\begin{array}{c}\mathrm{I} 6,33 \\
\%\end{array}$ \\
\hline 2 & $\begin{array}{l}46- \\
65\end{array}$ & 18 & $\begin{array}{c}36,73 \\
\%\end{array}$ & I I & $\begin{array}{c}22,45 \\
\%\end{array}$ \\
\hline 3 & $>65$ & 6 & $\begin{array}{c}\mathrm{I} 2,24 \\
\%\end{array}$ & 4 & $8,16 \%$ \\
\hline & Total & 26 & $\begin{array}{c}53,06 \\
\%\end{array}$ & 23 & $\begin{array}{c}46,94 \\
\%\end{array}$ \\
\hline
\end{tabular}

Hasil dari Tabel I menunjukkan gagal jantung lebih banyak terjadi pada pasien yang berjenis kelamin laki-laki sebanyak 26 pasien (53.06\%) dibandingkan dengan perempuan sebanyak 23 pasien (46.94\%). Persentase penderita gagal jantung laki-laki yang lebih tinggi dibanding dengan perempuan dalam penelitian ini sesuai dengan teori yang menyatakan bahwa laki-laki memiliki resiko gagal jantung 2 kali lebih besar daripada perempuan (Pugsley, 2006). Hal tersebut dapat terjadi karena pada umumnya kaum laki-laki cenderung memiliki kebiasaan yang dapat memengaruhi kesehatan. Salah satu perilaku yang memiliki resiko terhadap kesehatan adalah merokok yang dapat menyebabkan seseorang berisiko menderita gagal jantung 2 kali lebih tinggi sehingga berdampak terhadap kualitas hidup pasien.

Persentase yang diperoleh menunjukkan pada rentan usia 25-45 tahun terdapat 10 pasien (20,4I\%). Pada usia 45-65 tahun terdapat 29 pasien $(59,18 \%)$, serta usia $>65$ tahun terdapat I0 pasien (20,40\%). Peningkatan umur akan meningkatkan risiko terjadinya gagal jantung (Semeltzer, 2002). Hal ini berkaitan dengan proses menua yang menyebabkan peningkatan proses aterosklerosis pada pembuluh darah. Aterosklerosis menyebabkan terganggunya aliran darah ke organ jantung sehingga terjadi ketidakseimbangan antara kebutuhan oksigen miokardium dengan suplay oksigen.

Tabel 2. Karakteristik pasien berdasarkan Penyakit Penyerta

\begin{tabular}{lcc}
\hline \multicolumn{1}{c}{ Penyakit Penyerta } & $\begin{array}{c}\text { Jumlah } \\
\text { Kasus }\end{array}$ & $\begin{array}{c}\text { Persentase\% } \\
\mathbf{n}=\mathbf{4 9}\end{array}$ \\
\hline CHF & $\mathrm{I} 0$ & $20,4 \mathrm{I}$ \\
CHF, Diabetes Meilitus, & 3 & 6,12 \\
CAD & & 2,04 \\
CHF. Hipertensi & $\mathrm{I}$ & 2,04 \\
CHF, Ischaemic Heart & $\mathrm{I}$ & 2,04 \\
Disease & & 2,04 \\
CHF, Iskemia & $\mathrm{I}$ & 2,04 \\
Kardiovaskular & 6 & $\mathrm{I} 2,24$ \\
CHD, AF & 2 & 4,08 \\
CHF, AF, ICM & 7 & $\mathrm{I} 4,29$ \\
CHF, CAD & 4 & 8,16 \\
CHF, CAD, ICM & $\mathrm{I}$ & 2,04 \\
CHF, CHD & 6 & $\mathrm{I} 2,24$ \\
CHF, DCM & 4 & 8,16 \\
CHF, ICM & 3 & 6,12 \\
CHF, RHD & & \\
\hline
\end{tabular}

Gagal jantung dengan kondisi klinis diantaranya CAD (Coronary Artery Disease) Penyakit arteri koroner adalah penyempitan atau penyumbatan arteri koroner, arteri yang menyalurkan darah ke otot jantung.

Hipertensi atau tekanan darah tinggi ditandai dengan kenaikan tekanan darah yang melebihi batas normal yaitu $140 / 90 \mathrm{mmHg}$. Hipertensi telah dibuktikan meningkatkan risiko terjadinya gagal jantung pada beberapa penelitian. Penelitian yang dilakukan oleh Anggraini (2008) menemukan bahwa pada pasien rawat inap gagal jantung kongestif yang berusia 45 tahun keatas, positif mengalami hipertrofi ventrikel kiri dan memiliki riwayat hipertensi sebanyak 50,6\%.

Iskemia Kardiovaskular atau Penyakit Jantung Iskemia (PJI), dikenal juga Penyakit arteri koroner (PAK), didefinisikan sebagai kekurangan oksigen dan penurunan atau tidak adanya aliran darah ke miokardium yang disebabkan oleh penyempitan atau terhalangnya arteri koroner.

Penyakit Jantung Koroner (PJK) terjadi karena rusaknya dinding pembuluh darah yang disebabkan oleh beberapa faktor risiko seperti radikal bebas yang terkandung dalam rokok dan 
polusi, kolesterol tinggi dan kardometabolik sindrom. Akibatnya fungsi jantung terganggu karena harus bekerja lebih keras untuk memompa aliran darah, sehingga aliran darah ke otot jantung berkurang dan menyebabkan serangan jantung yang akhirnya menyebabkan gagal jantung. (Russel, 20I I)

Diabetes merupakan kasus besar lainnya dirumah sakit sebagai penyebab gagal jantung, yang memberikan kontribusi pada morbiditas dan kematian dini pada pasien. Diabetes melitus ditandai dengan kadar gula darah yang lebih dari kadar gula darah normal yaitu $200 \mathrm{mg} / \mathrm{dl}$. Berdasarkan hasil analisis diketahui bahwa dari 49 pasien yang menderita CHF di RSUD
Provinsi Nusa Tenggara Barat terdapat sebanyak 3 pasien (6,I2 \%) yang memiliki riwayat diabetes melitus.

Atrial Fibrilasi (AF) adalah aritmia yang mempengaruhi sebanyak 10-30\% pada pasien gagal jantung. Tingginya angka kejadian AF pada gagal jantung dikarenakan masing-masing dari dua penyakit ini memiliki presdiposisi satu sama lain. Adanya AF dalam gagal jantung dapat menimbulkan efek yang merugikan seperti peningkatan resiko tromboemboli sekunder di atrium, menurunnya curah jantung karena penurunan kerja atrium terhadap pengisisan ventrikel sehingga jantung akan membesar .

Tabel 3. Penggunaan obat antihipertensi pada pasien gagal ginjal kronik di instalasi rawat inap RSUD Provinsi NTB.

\begin{tabular}{|c|c|c|c|}
\hline Terapi Antihipertensi & Nama Obat & $\begin{array}{l}\text { Jumlah } \\
\text { Pasien }\end{array}$ & $\begin{array}{l}\text { Persentase } \\
\%(n=49)\end{array}$ \\
\hline \multicolumn{4}{|l|}{ Tunggal } \\
\hline$\beta$-Bloker & Bisoprolol & $\mathrm{I}$ & 2,04 \\
\hline ACEI & Ramipril & I & 2,04 \\
\hline $\mathrm{ARB}$ & Candesartan & $\mathrm{I}$ & 2,04 \\
\hline \multicolumn{4}{|l|}{2 kombinasi } \\
\hline Diuretik + Diuretik & Furosemid + Spironolactone & 6 & 12,24 \\
\hline Diuretik $+\beta$-Bloker & Furosemid + Bisoprolol & 2 & 4,08 \\
\hline$\beta$-Bloker $+C C B$ & Bisoprolol + Amlodipin & $\mathrm{I}$ & 2,04 \\
\hline$\beta$-Bloker + ARB & Bisoprolol + Candesartan & 6 & $\mathrm{I} 2,24$ \\
\hline $\begin{array}{l}\beta \text {-Bloker }+ \text { ACEI } \\
3 \text { kombinasi }\end{array}$ & \multicolumn{2}{|c|}{3 kombinasi } & $\mathrm{I} 2,24$ \\
\hline $\begin{array}{l}\text { Diuretik + Diuretik }+ \\
\text { ACEI }\end{array}$ & $\begin{array}{l}\text { Furosemid }+ \text { Spironolactone }+ \\
\text { Ramipril }\end{array}$ & 3 & 6,12 \\
\hline $\begin{array}{l}\text { Diuretik + Diuretik }+ \\
\mathrm{ARB}\end{array}$ & $\begin{array}{l}\text { Furosemid }+ \text { Spironolactone }+ \\
\text { Candesartan }\end{array}$ & I & 2,04 \\
\hline $\begin{array}{l}\text { Diuretik }+ \text { Diuretik }+ \\
\beta \text {-Bloker }\end{array}$ & $\begin{array}{l}\text { Furosemid }+ \text { spironolactone }+ \\
\text { propanolol }\end{array}$ & $\mathrm{I}$ & 2,04 \\
\hline Diuretik $+\beta$-Bloker + & Furosemid + Bisoprolol + Ramipril & 2 & 4,08 \\
\hline ACEI & Furosemid + Bisoprolol + Lisinopril & $\mathrm{I}$ & 2,04 \\
\hline $\begin{array}{l}\text { Diuretik }+\beta \text {-Bloker }+ \\
\text { ARB } \\
4 \text { kombinasi }\end{array}$ & Furosemid + Bisoprolol + Candesartan & 3 & 6,12 \\
\hline \multirow[t]{2}{*}{$\begin{array}{l}\text { Diuretik }+ \text { Diuretik }+ \\
\beta \text {-Bloker }+ \text { ARB }\end{array}$} & $\begin{array}{l}\text { Furosemid }+ \text { Spironolactone }+ \\
\text { bisoprolol }+ \text { valsartan }\end{array}$ & I & 2,04 \\
\hline & $\begin{array}{l}\text { Furosemid }+ \text { spirinolactone }+ \\
\text { Bisoprolol }+ \text { candesartan }\end{array}$ & I & 2,04 \\
\hline $\begin{array}{l}\text { Diuretik }+ \text { Diuretik }+ \\
\beta \text {-Bloker }+ \text { CCB }\end{array}$ & $\begin{array}{l}\text { Furosemid }+ \text { spirinolactone }+ \\
\text { Bisoprolol }+ \text { Amlodipin }\end{array}$ & I & 2,04 \\
\hline \multirow[t]{2}{*}{$\begin{array}{l}\text { Diuretik + Diuretik + } \\
\beta \text {-Bloker + ACEI }\end{array}$} & $\begin{array}{l}\text { Furosemid }+ \text { spirinolactone }+ \\
\text { Bisoprolol }+ \text { Ramipril }\end{array}$ & 6 & $\mathrm{I} 2,24$ \\
\hline & $\begin{array}{l}\text { Furosemid }+ \text { spirinolactone }+ \\
\text { Bisoprolol }+ \text { lisinopril }\end{array}$ & 4 & 8,16 \\
\hline $\begin{array}{l}\text { Diuretik + ARB + } \\
\beta \text {-Bloker + CCB }\end{array}$ & $\begin{array}{l}\text { Furosemid }+ \text { Candesartan }+ \text { Bisoprolol } \\
+ \text { Amlodipin }\end{array}$ & I & 2,04 \\
\hline
\end{tabular}


Berdasarkan tabel 4.3 menunjukkan penggunaan antihipertensi yang paling banyak digunakan pada pasien yang memiliki penyakit hipertensi diikuti dengan penyakit penyerta gagal jantung adalah golongan $\beta$-Blocker yaitu Bisoprolol sebanyak 35 pasien (71,43\%). Kemudian diikuti dengan antihipertensi golongan Diuretik Kuat yaitu Furosemid sebanyak 33 pasien (67,35\%). Penggunaan $\beta$ Bloker pada pasien gagal jantung merupakan drug of choice dan telah terbukti dapat meningkatkan Ejection Fraction, memperbaiki gejala, dan menurunkan angka kematian pada pasien gagal jantung. Golongan obat yang bekerja dengan menghambat interaksi epinefrin, norepinefrin, dan obat-obatan simpatomimetik dengan reseptor $\beta$ (beta).

Pada golongan diuretik penggunaan obat furosemid ini untuk mengurangi udema pada pasien Gagal Jantung. Mekanisme kerja obat furosemide dengan cara menghambat reabsorbpsi $\mathrm{NaCl}$ dalam ansa Henle asendens segmen tebal. Furosemid bekerja dengan cara menghambat kotranspor $\mathrm{Na}^{+} / \mathrm{K}^{+} / \mathrm{Cl}^{-} . \mathrm{Na}^{+}$ secara aktif ditranspor keluar sel ke dalam interstisium oleh pompa yang tergantung pada $\mathrm{Na}^{+} / \mathrm{K}^{+}$-ATPase di membrane basolateral. Hal ini akan menyebabkan terjadinya diuresis dan berakhir dengan penurunan tekanan darah (Guyon, 2008). Spironolakton merupakan obat hemat kalium yang dapat dikombinasikan dengan furosemide. Mekanisme kerja obat spironolakton adalah dengan cara memblokade ikatan aldosteron pada reseptor sitoplasma sehingga meningkatkan ekskresi $\mathrm{Na}^{+}\left(\mathrm{Cl}^{-}\right.$dan $\left.\mathrm{H}_{2} \mathrm{O}\right)$ dan menurunkan sekresi $\mathrm{K}^{+}$yang diperkuat oleh listrik (Guyon, 2008)(Kabo, 20I2). Hal ini menyebabkan pengeluaran kalium akan ditahan sehingga tidak terjadi hipokalemia (Kabo, 2012).

Penggunaan Angiotensin Reseptor Bloker (ARB) juga diharapkan dapat menghambat sebagian besar efek negatif dari sistem Renin Angiotensin Aldosteron (RAA). Mekanisme kerja ARB dengan cara mengikat reseptor Angiotensin Tipe I (ATI) yang terdapat pada otot polos pembuluh darah, kelenjar adrenal dan jaringan lainnya. ACE-Inhibitor bekerja dengan cara memblokade fungsi sistem RAA, dimana obat golongan ACE-Inhibitor ini menekan efek vasokonstriksi angiotensin II dalam susunan pembuluh darah sehingga mengurangi resistensi perifer total dalam tekanan darah, menyebabkan netriuresis dan diuresis yang membantu efek penurunan takanan darah dan membantu untuk mengembalikan edema pulmonal sistemik dan remodeling jantung yang berperan pada gejala dan progresivitas gagal jantung (Guyon, 2008) (Kabo, 2012) Pengobatan lainnya adalah pengobatan menggunakan obat golongan Calcium Chanel Blocker (CCB). Pada kasus ini obat golongan CCB digunakan untuk pasien gagal jantung dengan komorbid Penyakit Jantung Koroner (PJK) dan hipertensi. Penggunaan CCB dapat menurunkan beban jantung karena menurunkan afterload dan preload, meningkatkan aliran darah koroner karena melebarkan pembuluh darah koroner dan menghambat atherosklerosis karena dapat mencegah deskuamasi sel endotel akibat berbagai ransangan (Kabo, 2012).

Tabel 4. Analisis Ketepatan Terapi.

\begin{tabular}{clc}
\hline No & Parameter & $\begin{array}{c}\text { Persentase } \% \\
(\mathrm{n}=49)\end{array}$ \\
\hline I & Tepat Indikasi & I00\% \\
2 & Tepat Pasien & $100 \%$ \\
3 & Tepat Obat & $100 \%$ \\
4 & Tepat Dosis & $73,47 \%$ \\
5 & Tepat Frekuensi & $100 \%$ \\
\hline
\end{tabular}

ketepatan indikasi pada seluruh sampel pasien gagal jantung di Rumah Sakit Umum Daerah Provinsi NTB adalah sebesar 100\%. Hal ini dikarenakan obat gagal jantung diberikan pada pasien yang terdiagnosis gagal jantung dan gejala yang dialami pasien. ketepatan pasien atau diagnosa pada seluruh sampel pasien gagal jantung di Rumah Sakit Umum Daerah Provinsi Nusa Tenggara Barat adalah sebesar I00\%. Evaluasi ketepatan pasien pada penggunaan antihipertensi dilakukan dengan membandikan obat antihipertensi yang diberikan di RSUD Provinsi Nusa Tenggara Barat dengan Guidline NYHA dan JNC VIII. Penyakit penyerta hipertensi berhubungan dengan peningkatan risiko menjadi gagal jantung. Terapi antihipertensi secara jelas menurunkan angka kejadian gagal jantung (kecuali penghambat adrenoreseptor alfa, yang kurang efektif dibanding antihipertensi lain dalam pencegahan gagal jantung).

Ketepatan obat sebanyak 49 kasus dengan ketepatan 100\%. Evaluasi ketepatan obat pada penggunaan antihipertensi dilakukan dengan membandikan obat antihipertensi yang diberikan di RSUD Provinsi Nusa Tenggara 
Barat dengan Formularium Nasional dan Formularium RSUD Provinsi Nusa Tenggara tahun 2019 (Revisi ke-6). Terapi antihipertensi yang diberikan pada pasien gagal jantung dapat berupa terapi tunggal (monoterapi) maupun terapi kombinasi dari dua, tiga atau empat antihipertensi (Sassen JJ, 2008).

Tepat dosis adalah pemilihan dosis yang tepat untuk pasien yang disertai dengan frekuensi pemberian obatnya yang disesuaikan dengan Drug Dosing Heart Failur ketepatan dosis sebanyak 49 kasus dengan ketepatan $73,47 \%$. Terapi antihipertensi golongan loop diuretic lebih sering diresepkan dari pada golongan tiazid karena loop diuretic mempunyai efisiensi diuresis dan natriuresis lebih tinggi. Penggunaan furosemide biasanya dimulai dari dosis 20-40 mg sehari sampai memenuhi dosis target $40-240 \mathrm{mg} / \mathrm{hari}$, obat ini juga bisa diberikan secara intravena maupun peroral sesaui dengan keadaan pasien (JNC VIII)(NYHA, 20I2). Dari 33 pasien yang mendapatkan furosemide, I3 diantaranya mendapatkan dosis kurang yaitu $20 \mathrm{mg}$ satu kali sehari, dosis furosemid dianalisis berdasarkan Formularium Nasional dan Formularium RSUD Provinsi Nusa Tenggara tahun 2019 (Revisi ke-6).

Tepat frekuensi atau interval pemberian obat adalah ketepatan pemberian obat sesuai dengan sifat obat dan profil farmakokinetiknya. Tepat frekuensi sebanyak 49 kasus dengan analisis ketepatan frekuensi sebesar 100\%. Evaluasi ketepatan frekuensi pada penggunaan antihipertensi dilakukan dengan membandikan frekuensi antihipertensi yang diberikan di RSUD Provinsi Nusa Tenggara Barat dengan Formularium Nasional dan Formularium RSUD Provinsi Nusa Tenggara tahun 2019 (Revisi ke-6). Dikatakan tepat frekuensi bila obat digunakan sesuai dengan frekuensi pemberian yang ditetapkan (Inrud, I999).

\section{Simpulan}

Berdasarkan penelitian yang telah dilakukan terhadap 49 sampel tentang penggunaan obat antihipertensi pada pasien gagal jantung di Poli Jantung RSUD Provinsi Nusa Tenggara Barat dapat disimpulkan bahwa : Dari penelitian ini didapat untuk Kategori ketepatan didapat untuk tepat indikasi 100\%, untuk tepat pasien $100 \%$, tepat obat $100 \%$, tepat dosis $73,47 \%$ dan tepat frekuensi $100 \%$. Adapun obat antihipertensi yang digunakan yakni furosemid $(67,36 \%)$, spirinolactone (46,94\%), ramipril (34,69\%), lisinopril
(10,20\%), valsartan (2,04\%), candesartan (24,49\%), amlodipin (6,12\%), Bisoprolol $(71,43 \%)$ dan propanolol $(2,04 \%)$.

\section{Ucapan terima kasih}

Terimakasih kepada ibu dan Bapak dosen yang telah memberikan mbingannya kepada saya sehingga karya tulis ini bisa sampai selesai. Terimaksi pula kepada teman-teman yang telah membantu dalam penulisan karya tulis ilmiah ini.

\section{Daftar Pustaka}

Alhusseiny A.H., dan Al Nimer M.S.M. (2013). Heart Failure: Discrepancy Between NYHA Functional Classification , Serum NT-pro Brain Natriuretic Peptide and Ejection Fraction, European Journal of General Medicine IO(I), 26-3I.

American Heart Association. (2012). About heart failure. 3 Februari 2019). http://www.heart.org/HEARTORG/ Conditions/HeartFailure/AboutHeart F ailure/About-HeartFailure_UCM_002044_Article.jsp

Anonim, Perhimpunan Dokter Spesialis Kardiovaskular Indonesia. (2015). Pedoman Tatalaksana Gagal Jantung. Edisi Pertama. Jakarta: Indonesian Heart Association

Anonim, Riset Kesehatan Dasar, (2018), Pedoman Pewawancara Petugas Pengumpul Data. Jakarta : Badan Litbangkes, Depkes RI, 2018

Guyon AC, Hall JE. (2008). Buku Ajar Fisiologi Kedokteran. Jakarta: EGC.

JNC-VIII. (20I4). The Eight Report of the Joint National Committee. Hypertension Guidelines: An In-Depth Guide. Am J Manag Care

Kabo P. (20I2). Bagaimana Menggunakan Obat-Obat Kardiovaskular Secara Rasional. Jakarta: Fakultas Kedokteran Universitas Indonesia.

Mulyani, Y., (2005), Evaluasi Penggunaan Obat pada Penderita Gangguan Fungsi Ginjal, Usia lanjut, Hipertensi dan Diabetes Mellitus di bagian Ilmu Penyakit Dalam Perjan Rumah Sakit Hasan Sadikin Bandung, Abstrak, (online),

(http://digilib.itb.ac.id/gdl.php?mod= browse\&op $=$ read\&id $=$ diakses 5 Februari 2019). 
Notoatmodjo,S. (20I2). Metodologi Penelitian Kesehatan. Jakarta: Rineka Cipta

Syamsudin. (201I). Buku Ajar Farmakoterapi Kardiovaskular Dan Renal. Jakarta: Penerbit Salemba Medika pp 3 I

WHO. (2016). Prevention of Cardiovascular Disease. WHO Epidemiologi Sub Region AFRD and AFRE. Genewa. 